\title{
Re-Indigenizing Romanticism:
}

\section{A Forum}

\section{Studies in Romanticism}

Editors: Nikki Hessell (Pākehā/settler, Te Herenga Waka-Victoria University of Wellington) and Liz Potter (Osage, University of York)

Deadline: October 1, 2021

Essay Length: 3,000 words

Review Process: Anonymous peer review

Projected Publication Date: Fall 2022

Despite the essential role of Indigenous peoples and knowledges in Romanticism, there has yet to be a serious reconsideration of British Romanticism from this perspective. The methods and critical practices of Indigenous nations and traditions throughout the Americas, the Pacific, Asia, and Africa, will enhance our broader understanding of Romanticism as a global phenomenon and a field of study.

For this forum, we are seeking short essays from writers inside and beyond the academy on the topic of "Re-Indigenizing Romanticism." The forum will prioritize approaches to Romanticism that originate in specific Indigenous epistemologies, rather than general readings of Indigenous peoples as subjects within the canon or indigeneity as a homogenous category. The prioritized approaches might include:

- Methodologies that center nation-specific places and knowledges, genealogy, relations with land, water, and other-than-human beings, kinship, and/or sovereignty

- Critical readings of material texts (carvings, weaving, beading, etc.)

- Applications of the work of key Indigenous literary critics (such as Warrior, Allen, Te Punga Somerville, Justice, Womack, and Lyons) or Indigenous scholars in other disciplines to Romantic texts and issues

- Readings of Indigenous authors as Romantic, proto-Romantic, foundational to Romanticism, or anti-Romantic, in any period of history

- Reimaginings of what constitutes the "Romantic period"

- Indigenous-language translations of Romantic texts or translations of Indigenouslanguage Romantic texts

- Correspondence between Indigenous peoples and Anglo-Europeans that displays sentimentality or Romantic tropes

- Indigenous production of goods/souvenirs for European tourists

- Indigenous-authored creative writing that engages with British Romanticism and its texts as a form of critical practice

- Collaborative or co-authored scholarship that encompasses Indigenous contributors and voices

- Treaty-based writing models, in which settler contributors partner with Indigenous contributors with whom they have established relationships

- Story-based or conversation-based contributions between speakers/writers 
- Reconsiderations of Romanticism's role in colonization and the dispossession of Indigenous lands and sovereignty.

Please submit essays and brief biographies as Word documents to both Liz (emp534@york.ac.uk) and Nikki (nikki.hessell@vuw.ac.nz).

Enquiries are welcome and can be directed to either Nikki or Liz. 